Damian Koclęga, Agnieszka Radziszewska, Sławomir Kąc, Włodzimierz Zowczak, Aleksandra Dębowska, Mateusz Jędrusik, Paweł Petrzak

\title{
Characterization of microstructure and mechanical properties of laser-welded stainless steels
}

\section{Charakterystyka struktury i właściwości mechanicznych złączy spawanych wiązką laserową stali nierdzewnych}

\begin{abstract}
This work presents the laser welding of dissimilar X12CrCoWVNbN12-2-2 and X10CrNi18-10 steels. This system is of interest, as laser welding offers new flexibility in the joining of metals and laser welds (LWs) and are usually of high quality; they are obtained only after the optimization of process parameters. The aim of the work was to investigate the microstructure, chemical composition, and hardness changes of laser-welded steels. After laser welding, two zones were generated in the processed materials: a fusion zone and a heat-affected zone. Due to solidification, a refinement of the microstructure occurred in the fusion zone. Examinations of the chemical composition of particular melted areas showed the occurrence of $\mathrm{Nb}$-rich precipitations. The laser welding of steels led to increased hardness in the fusion zone (about 240-530 HV0.3).
\end{abstract}

Keywords: laser welding, stainless steel, microstructure, chemical composition, hardness

\section{Streszczenie}

W pracy przedstawiono wyniki badań różnorodnych złączy spawanych wiązką laserową stali X12CrCoWVNbN12-2-2 i X10CrNi18-10. Zastosowanie wiązki laserowej jest wysoce użyteczne ze względu na nowe możliwości procesu wytwarzania i zwykle wysoką jakość złączy po optymalizacji procesu. Celem pracy była ocena mikrostruktury, składu chemicznego i zmian twardości w złączach spawanych wiązką lasera. Po procesie spawania zaobserwowano dwa główne obszary, tj. linię wtopienia i strefę wpływu ciepła. Podczas krystalizacji w obszarze przy linii wtopienia zaobserwowano rozdrobnienie struktury. Szczegółowa analiza składu chemicznego ujawniła

Damian Koclęga M.Sc., Agnieszka Radziszewska Ph.D. Eng., Sławomir Kąc Ph.D. Eng., Aleksandra Dębowska M.Sc. Eng., Mateusz Jędrusik M.Sc. Eng., Paweł Petrzak M.Sc. Eng.: AGH University of Science and Technology, Faculty of Metal Engineering and Industrial Computer Science, Krakow, Poland, Włodzimierz Zowczak Ph.D. Eng.: Kielce University of Technology, Faculty of Mechatronics and Mechanical Engineering, Poland; dkoclega@agh.edu.pl 
występowania wydzieleń bogatych w Nb w obszarze metalu stopionego. Zaobserwowano, że spawanie laserowe prowadzi do wzrostu twardości w obszarze przy linii wtopienia.

Słowa kluczowe: spawanie wiązką lasera, stal nierdzewna, mikrostruktura, skład chemiczny, twardość

\section{Introduction}

The development of modern boilers, industrial waste incinerators, metallurgical furnaces, and gas-turbine engines has been driven by the desire for ever-greater efficiency and increased performance. Increases in the power and efficiency of boilers, combustion chambers, and gas turbine engines can be achieved by increasing the operating temperature and gas pressure [1,2]. This can be attained by improving the cooling path within the turbine components, developing new heat-resistant materials, applying coatings, or a combination of these. Among the materials currently used to construct such elements are austenitic and martensitic stainless steels $[3,4]$. These steels are characterized by good corrosion resistance, oxidation resistance at elevated temperatures, strength and toughness, ductility, and fatigue strength [5-8]. The joining of these kinds of materials can be difficult; therefore, a novel technique is proposed (namely, laser welding). The general problems associated with welds in stainless steels are as follows: sensitization of the weld heat-affected zone, distortion of the weldments, and hot cracking in the welded metal. The application of classic arc welding techniques require the use of high-quality electrodes and filler material, for example. However, the modern technique of laser welding has no such requirements. The advantage of laser welding over other conventional welding methods is that the laser beam can be narrowly focused on a small area, producing a high-intensity heat source $[9,10]$. This technique also offers the possibility of welding materials with a high aspect ratio, small heat-affected zone, and high processing speed. The narrow heat-affected zone of laser welds limits thermal distortion and improves the metallurgical properties of welds as compared to classic arc welding techniques. A consequence of the narrow heat-affected zone and deep penetration is that it enhances mechanical properties such as fatigue strength and formability. The using of a laser beam leads to changes in the structural, physical, chemical, and mechanical properties in the particular areas of the processed objects [11]. Therefore, the proposed laser welding is a proper technique to joint dissimilar materials such as martensitic $(0.13 \% \mathrm{C}-11.4 \% \mathrm{Cr})$ to austenitic (X10CrNi18-10) stainless steels $[12,13]$. In laser welding, the weld material is a mixture of the two steels being joined.

This work is focused on welding martensitic $\mathrm{X} 12 \mathrm{CrCoWVNbN12-2-2}$ and austenitic $\mathrm{X} 10 \mathrm{CrNi18-10}$ stainless steels by means of the laser technique. The work presents the microstructure, chemical composition, and hardness of the resultant laser weld of stainless steels. 


\section{Materials and experimental procedures}

Laser welding has been used for welding $5-\mathrm{mm}$ sheets made of $18 \mathrm{Cr} 10 \mathrm{Ni}$ steel with

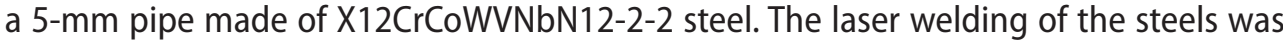
performed with a TRUMPF LASERCELL 1100 (TLC 1005) $\mathrm{CO}_{2}$ laser with continuous operation and a radiation wave length of $\lambda=10.6 \mu \mathrm{m}$. A bifocal welding head was used in the joining of these steels. The chemical composition of the X12CrCoWVNbN12-2-2 and X10CrNi18-10 stainless steels is shown in Table 1.

Table 1. Chemical composition of investigated laser-welded stainless steels (X12CrCoWVNbN12-2-2 and 18 (r10Ni)

\begin{tabular}{|c|c|c|c|c|c|c|}
\hline \multirow{4}{*}{$\begin{array}{c}\text { Element } \\
\text { wt. } \%\end{array}$} & C & Mn & $\mathrm{Cr}$ & Co & $\mathbf{N b}$ & $\mathbf{N i}$ \\
\hline & \multicolumn{6}{|c|}{ X12CrCoWVNbN12-2-2 - base material A (BM-A) } \\
\hline & 0.13 & 0.22 & 11.4 & 1.2 & 0.05 & 0.19 \\
\hline & \multicolumn{6}{|c|}{ X10CrNi18-10 - base material B (BM-B) } \\
\hline & 0.06 & 2 & 18 & - & 0.8 & 10 \\
\hline
\end{tabular}

The laser beam was positioned at the joint and moved up $2 \mathrm{~mm}$ in relation to the surface of the sample. Laser treatment was performed in a helium atmosphere (200 Pa; $18 \mathrm{l} / \mathrm{min}$ ) at four welding speed shifts (V) with respect to the stationary samples; namely, $18.3 \mathrm{~mm} / \mathrm{s}, 20 \mathrm{~mm} / \mathrm{s}, 21.7 \mathrm{~mm} / \mathrm{s}$, and $25 \mathrm{~mm} / \mathrm{s}$ at a laser beam power of $P=6 \mathrm{~kW}$. A shielding gas helium was used to protect the heated surface against oxidation. The schematic diagram of the laser-welded materials is shown in Figure 1. The stainless steels were butt welded, and full joint penetration was applied.

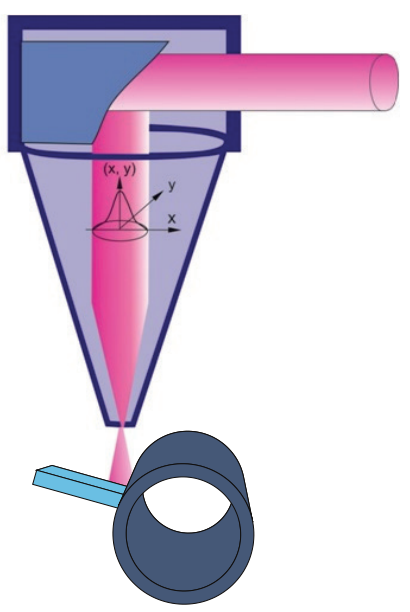

Fig. 1. Schematic of laser welding of examined materials (pipe and sheet) 
The microstructure of the laser-welded steels samples was examined with a Zeiss Axio Imager M1m visual light microscope (VLM) and FEI NOVA NANOSEM 450 Scanning Electron Microscope (SEM). Their chemical composition was examined with energy-dispersive spectroscopy (EDS). The microhardness of the LW materials were measured on transversal microsections along paths parallel to the surface with a Wolpert-Wilson TUKON 2500 microhardness tester by the Vickers (HV) method at a load of $9.8 \mathrm{~N}$. Three series of measurements for each sample were accomplished to verify the reproducibility of the data; the average values were reported.

\section{Results and discussion}

The microstructure of each weld was characterized using VLM. The VLM observations of the base materials revealed that the $\mathrm{X} 12 \mathrm{CrCoWVNbN12-2-2}$ steel was supplied in the normalized and tempered condition. This steel had high-tempered lath martensite of a subgrain structure with inclusions of carbides and carbonitrides (Fig. 2a). The carbides $\left(\mathrm{M}_{23} \mathrm{C}_{6}\right)$ are along the grain boundary of the former austenite and along the lath of the martensite [10]. The carbides can also be observed inside the ferrite subgrains. After heat treatment, the delta ferrite can form. The $18 \mathrm{Cr} 10 \mathrm{Ni}$ steels had an austenitic structure (Fig. 2b).

a)

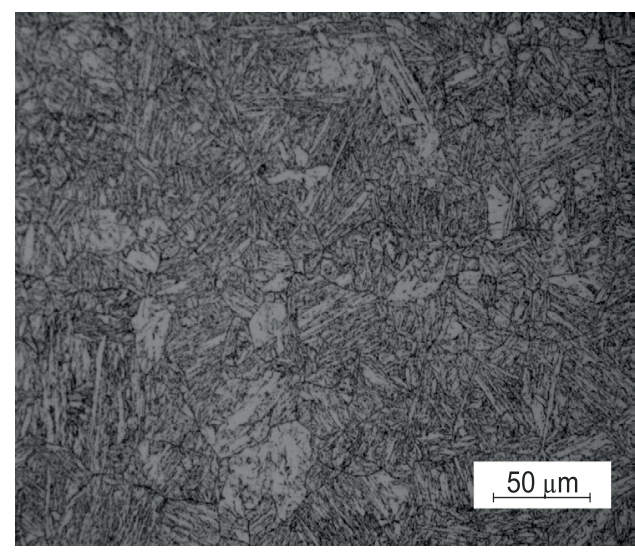

b)

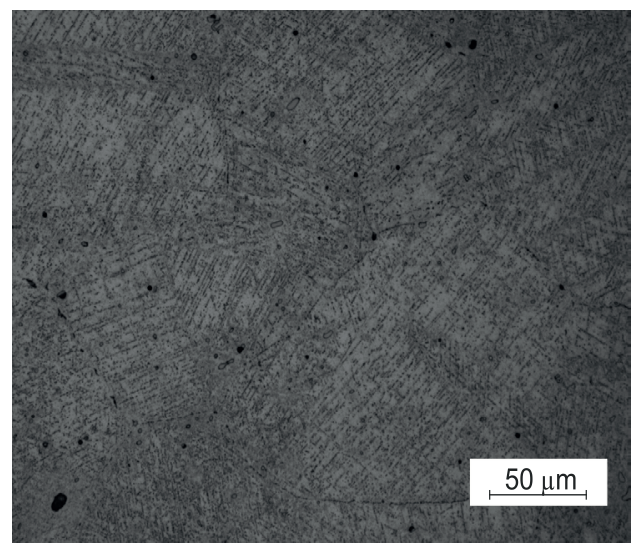

Fig. 2. Microstructure of base materials: a) martensitic X12CrCoWVNbN12-2-2 steel; b) austenitic X10CrNi18-10 steel

After laser welding the stainless steels, two zones were obtained; namely, the fusion zone (FZ) and heat-affected zone (HAZ) (Fig. 3). The fusion zone is a combination of both base steels. Helium were used as a shielding gas for the laser welding to create welds 
without porosity. The width of the beads at the top of the welds is greater than those deeper into the welds (Fig. 3). The difference between these values depends on the welding speed. The weld face is narrower when the welding speed is increased (Fig. 3). The solidification in the weld extends from the base material in the direction of the axis of the weld. As a result of the solidification characteristics of the welded materials and the tendency of hot cracking, the welds had a tendency to produce centerline weld cracks, especially in the case of applying lower welding speeds ( $18.8 \mathrm{~mm} / \mathrm{s}$ and $20 \mathrm{~mm} / \mathrm{s}$ ) (Figs. 3c, 3d).

a)

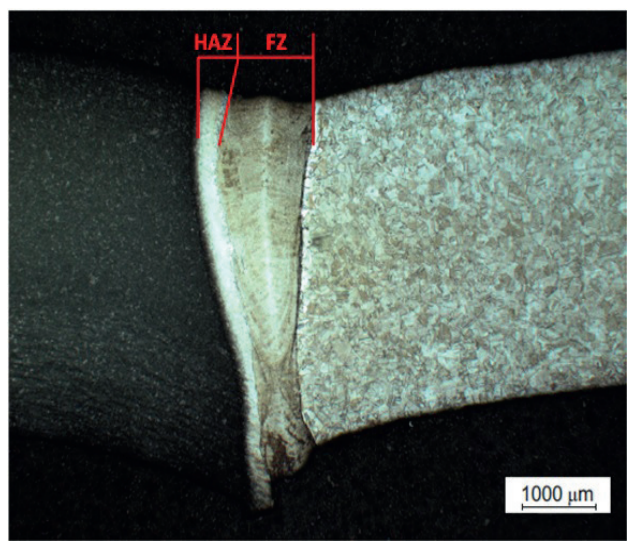

c)

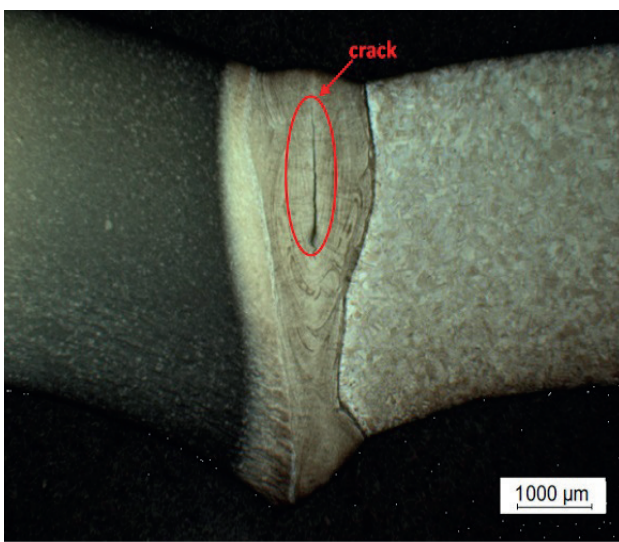

b)

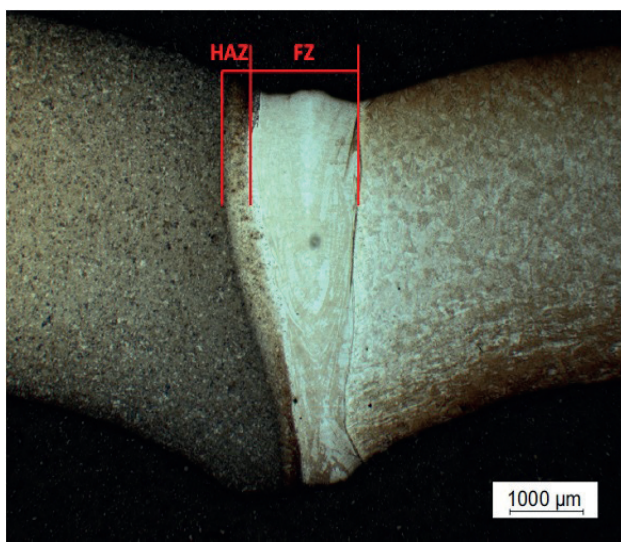

d)

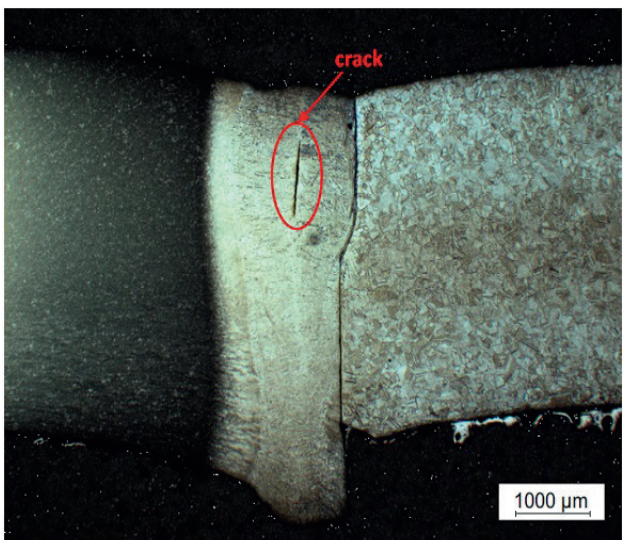

Fig. 3. Cross-sections of laser welds of $X 12 \mathrm{CrCoWVNbN12-2-2}$ and $X 10 \mathrm{CrNi18-10}$ steels: a) $V=25 \mathrm{~mm} / \mathrm{s}$; b) $V=21.7 \mathrm{~mm} / \mathrm{s}$; c) $V=20 \mathrm{~mm} / \mathrm{s}$; d) $V=18.3 \mathrm{~mm} / \mathrm{s}$

During the laser welding, the weld crystallizes and increases the tensile stresses. Due to these stresses, the material can deform and become characterized by the low 
ability to deform; therefore, it starts to crack [14]. Another reason for the solidification cracks can be the weld profile shape. The low width to depth ratio $(j)$ at around 0.3 of the laser welds causes restraint. When the penetration depth is too deep and the width of the weld is too thin, the crystals at the top of the fusion zone can lead to the closure of the liquid metal in the centerline of the weld. The non-crystallized metal did not have time to solidify; when the solidification fronts of the crystals meet each other, the cracking starts in the center of the weld [15].

Therefore, the weld shape must be carefully controlled during the laser welding. Increasing the welding speed to above $21 \mathrm{~mm} / \mathrm{s}$ resulted in welds without cracks (Fig. 4).

a)

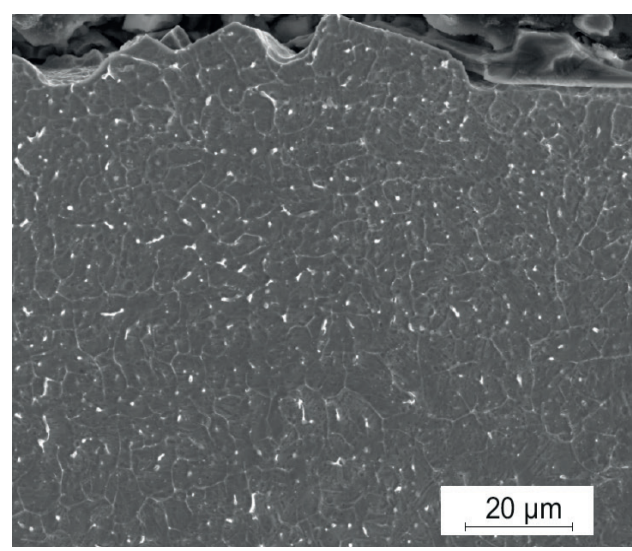

c)

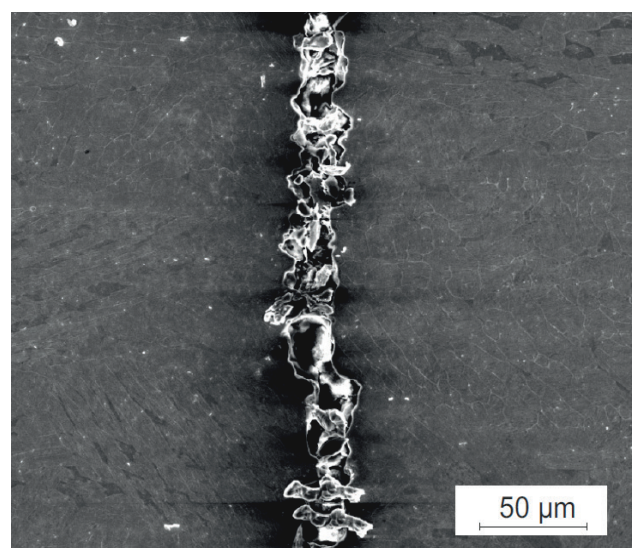

b)

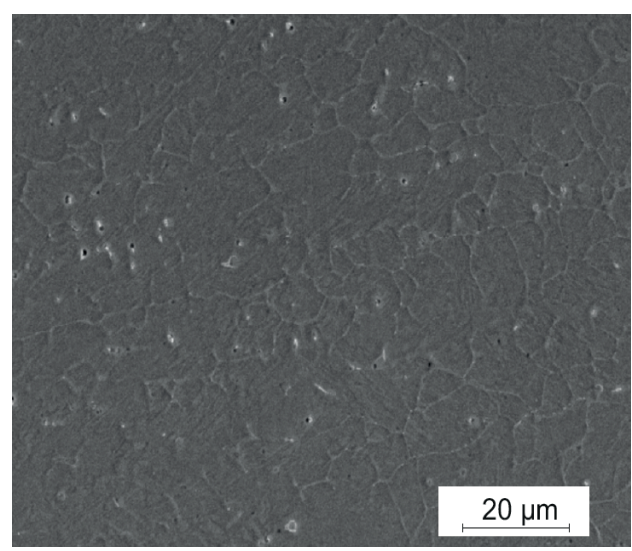

d)

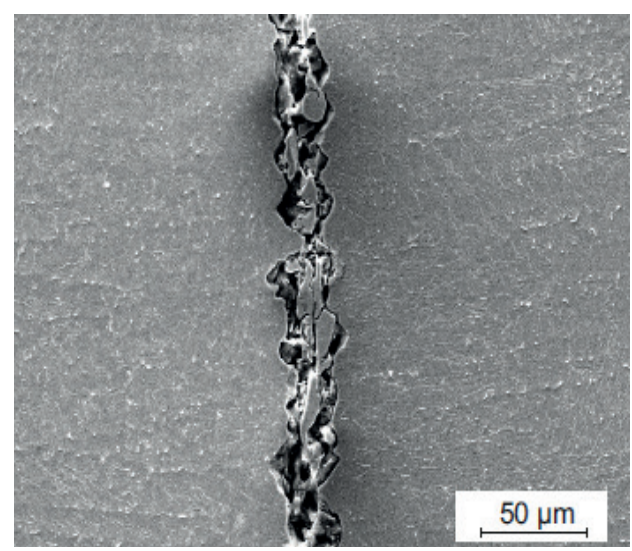

Fig. 4. SEM microstructure of fusion zones obtained after laser welding X12CrCoWVNbN12-2-2 and X10CrNi18-10 steels: a) $V=25 \mathrm{~mm} / \mathrm{s} ;$ b) $V=21.7 \mathrm{~mm} / \mathrm{s}$; c) $V=20 \mathrm{~mm} / \mathrm{s} ;$ d) $V=18.3 \mathrm{~mm} / \mathrm{s}$ 
The welds exhibited a grain refinement of the structure. Based on the Schaeffler diagram and its modifications, we can estimate the microstructure of the fusion zone in the joint of dissimilar metals $[16,17]$. As a consequence of the laser welding of

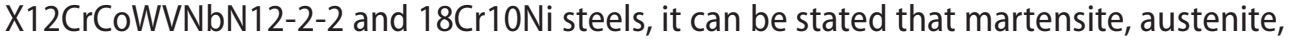
and about $1-2 \%$ of ferrite occur in the fusion zone (Fig. 4). In the fusion zone for all joints, precipitations showing higher concentrations of $\mathrm{Nb}$ were also visible (Fig. 5).

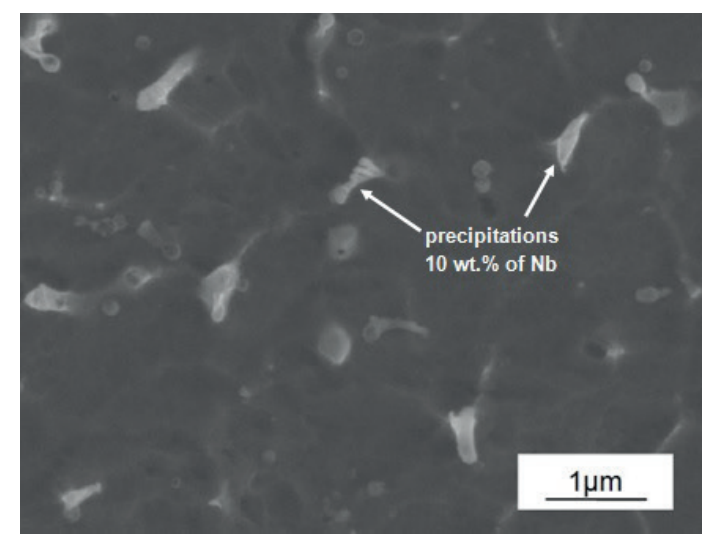

Fig. 5. SEM microstructure of fusion zone with precipitations rich in Nb (about 10 wt.\%)

Microstructural investigations of stainless steels (sheets and pipes) welded with $\mathrm{CO}_{2}$ laser radiation with a laser beam power of $P=6 \mathrm{~kW}$ show that the HAZ decreases with a welding speed of $V=18.3-25 \mathrm{~mm} / \mathrm{s}$ (Fig. 3). In the case of joining materials, the base martensitic steel has a clear heat-affected zone (Fig. 6a). Meanwhile, the HAZ is practically invisible in the case of the welding of austenitic stainless steel (Fig. 6b).

a)

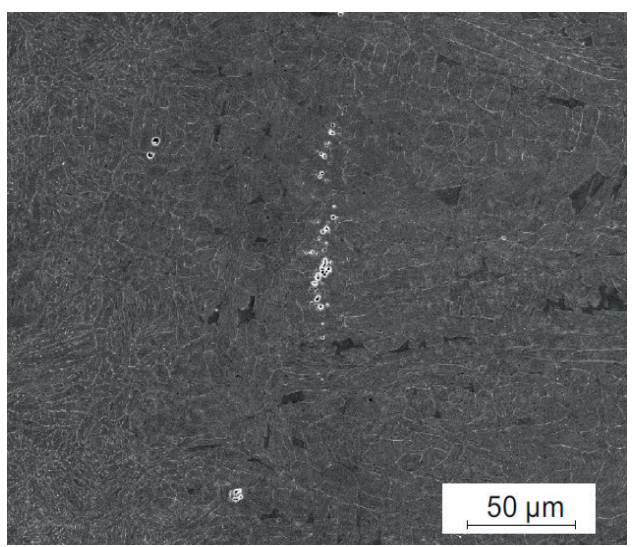

b)

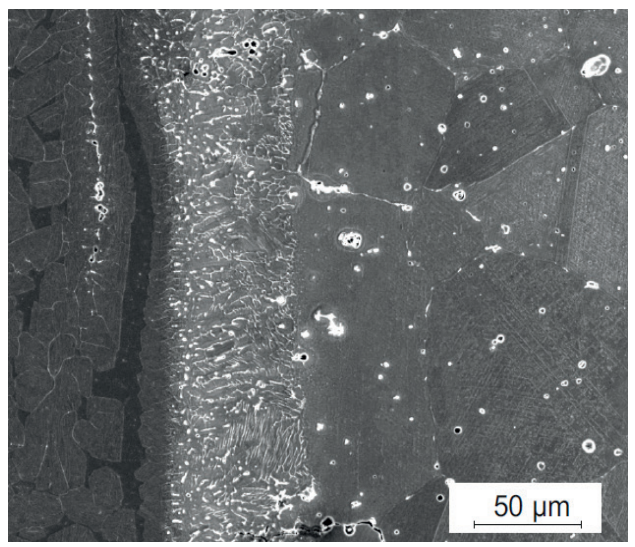

Fig. 6. SEM microstructure of: a) heat-affected zone obtained in X12CrCoWVNbN12-2-2 steel; b) fusion line from side of $X 10 \mathrm{CrNi18-10} \mathrm{steel}$ 
The welded steels were well-mixed by the laser beam action, and the element composition maps determined a homogenous distribution of $\mathrm{W}, \mathrm{Ni}, \mathrm{Co}, \mathrm{Mn}, \mathrm{Fe}$, and $\mathrm{Cr}$ from the top to the bottom of the welds (Fig. 7).

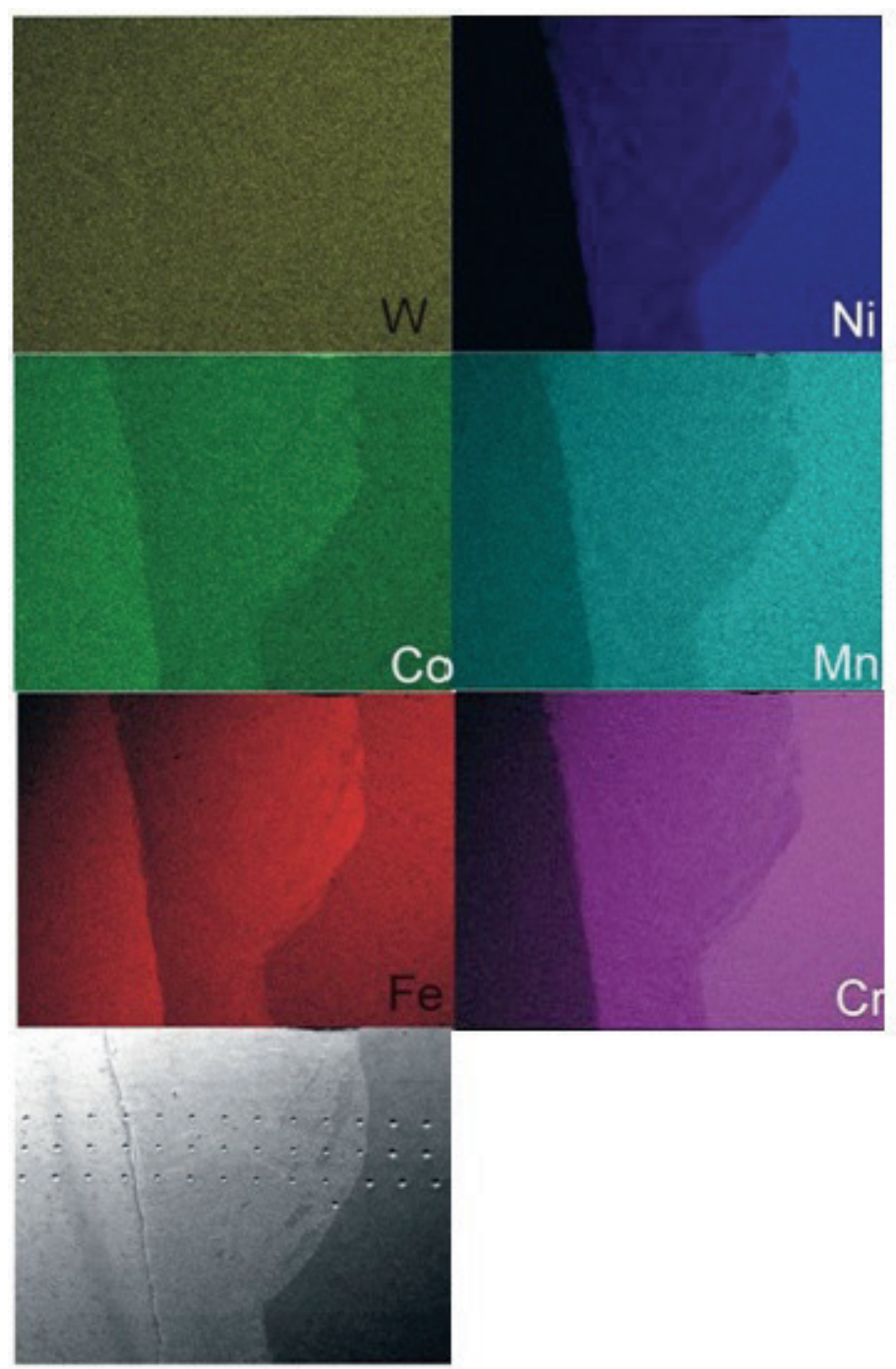

Fig. 7. Element maps of $\mathrm{W}, \mathrm{Ni}, \mathrm{Co}, \mathrm{Mn}, \mathrm{Fe}$, and $\mathrm{Cr}$ in laser weld of $\mathrm{X} 12 \mathrm{CrCoWVNbN12-2-2}$ and $X 10 \mathrm{CrNi18}-10$ steels $-V=21.7 \mathrm{~mm} / \mathrm{s}$

Figure 8 presents a scanning electron microscope image of the fusion zone microstructure at higher magnification as well as its spectrograms. As mentioned above, 
precipitations were visible in this area. A shift of the electron beam from the precipitation to the matrix showed that the precipitation is rich in niobium (about $10 \mathrm{wt} . \%$ ) and tungsten (about 3 wt.\%) (Fig. 8b). Neither element was visible in the base material (Fig. 8c). The chemical composition of selected areas are presented in Table 2.

a)

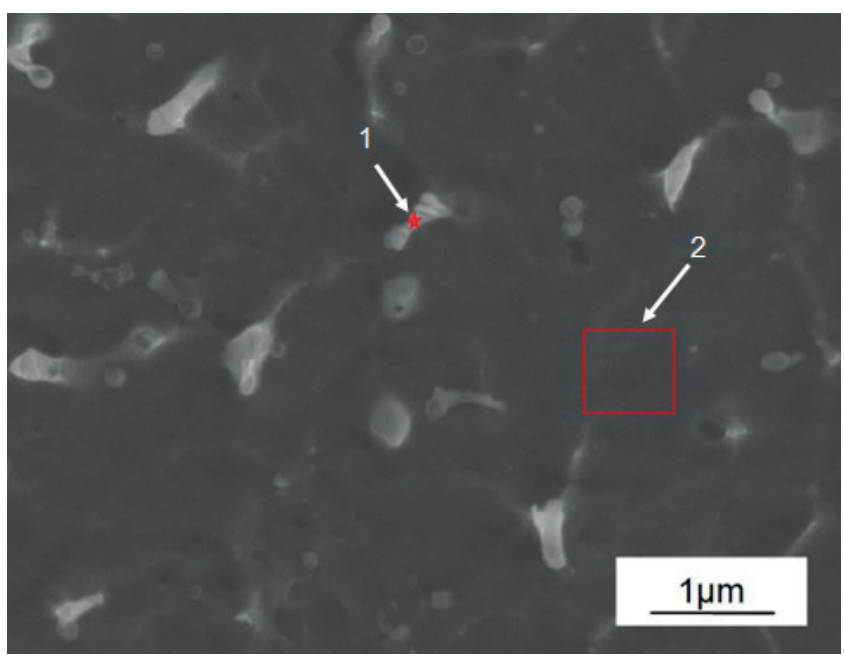

b)

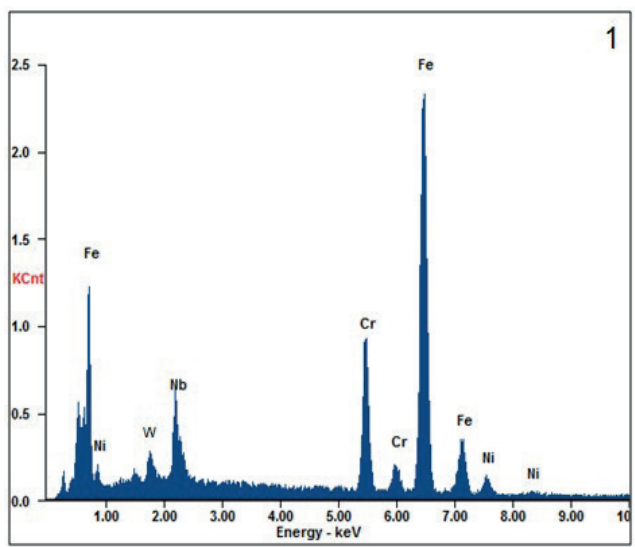

c)

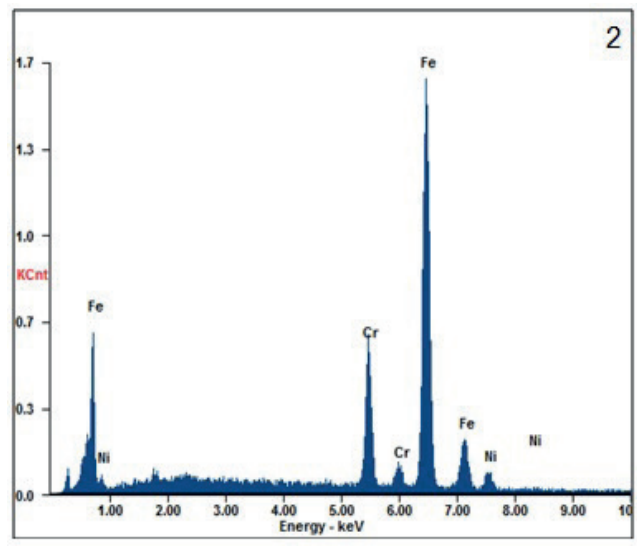

Fig. 8. SEM microstructure of fusion zone with precipitate rich in Nb (a); and EDS spectrograms: b) local microanalysis of niobium-rich precipitate (about $10 \mathrm{wt} . \%)$; c) local microanalysis of matrix were also visible 
Table 2. The chemical composition of selected areas (denoted by 1-2 in Figure 8a) of the fusion zone

\begin{tabular}{|c|c|c|}
\hline \multirow{2}{*}{$\begin{array}{l}\text { Element/ characteristic } \\
\text { X-ray line analysed }\end{array}$} & Point-1 & Area-2 \\
\hline & \multicolumn{2}{|c|}{ Weight \% } \\
\hline $\mathrm{Cr}-\mathrm{K}_{\mathrm{a}}$ & 15.7 & 15.9 \\
\hline $\mathrm{Fe}-\mathrm{K}_{\mathrm{a}}$ & 67 & 78.2 \\
\hline $\mathrm{Nb}-\mathrm{L}_{a}$ & 9.5 & - \\
\hline $\mathrm{Ni}-\mathrm{K}_{\mathrm{a}}$ & 4.6 & 5.9 \\
\hline W-M & 3.2 & - \\
\hline
\end{tabular}

The results of the weld hardness measurements are presented in Figure 9. They showed that the microhardness distribution in a cross-section of the fusion and heat-affected zones was not uniform. The graph presented a smooth transition from the high-hardness level produced within the fusion zone to that of the base materials. Different values of microhardness of the fusion zones were obtained by modifications of process parameters (laser-welding speed). The increase of welding speed of the laser beam resulted in an increase in the hardness (Fig. 9), which can be explained by the presence of a fine-crystalline structure, saturation with chromium, and the presence of martensite and $\mathrm{Nb}$-rich precipitations. The highest value of hardness of the fusion zone (about $530 \mathrm{HV} 0.3$ ) was obtained at a welding speed of $25 \mathrm{~mm} / \mathrm{s}$, while the lowest was $184 \mathrm{HV} 0.3$ for $18.3 \mathrm{~mm} / \mathrm{s}$. The microhardness of the heat-affected zone reached about $500 \mathrm{HV} 0.3$, and it decreased in the base materials.

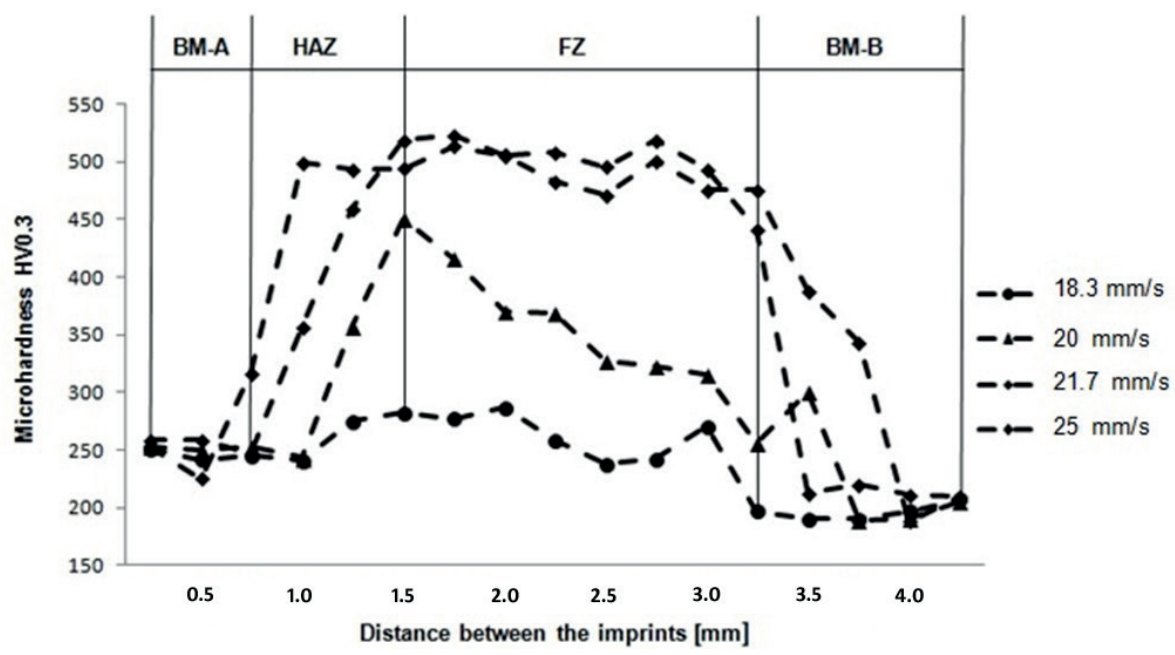

Fig. 9. Microhardness profiles on section of laser welds obtained for different welding speeds 


\section{Conclusions}

After the laser welding of stainless steels, two characteristic zones were generated: a fusion zone and a heat-affected zone. Structural examinations of the fusion zones showed the presence of considerable grain size reduction. Due to the solidification of a liquid laser pool, $\mathrm{Nb}$-rich precipitations appeared from the $\mathrm{Nb}$ present in the composition of the austenitic stainless steel. Element maps of $\mathrm{W}, \mathrm{Ni}, \mathrm{Co}, \mathrm{Mn}, \mathrm{Fe}$, and $\mathrm{Cr}$ from the laser welds presented their homogeneous distribution, while an EDS microanalysis of the fusion zones confirmed the occurrence of $\mathrm{Nb}$-rich precipitations. Modifications of the laser speed welding led to variations in the hardness of the fusion zones and heat-affected zones of the obtained laser welds of the steels. The laser welding of the steels led to an increase in the hardness of the fusion zone (up to about $500 \mathrm{HV} 0.3$ ) and that of the heat-affected zone (up to about $500 \mathrm{HV} 0.3$ ). The higher hardness of the fusion zone was related to the reduction of grain size in their microstructures and saturation of phases with the alloying element (which was due to the high crystallization rates) as well as the presence of martensite and $\mathrm{Nb}$-rich precipitations.

\section{Acknowledgement}

The present work was supported by The National Center of Research and Development, project no. PBS1/B5/13/2012 Las-Energ.

\section{References}

[1] Zhu F.: Microstructural Evolution in Austenitic Stainless Steels for Extended Life Power Station Applications. Ph.D. Thesis, Loughborough University, 2011

[2] Pańcikiewicz K., Tuz L., Ziewiec A., Żurek Z., Zielińska-Lipiec A., Kajda P.: Selected aspects of the welding alloys used at high temperature. In: Hernas A., Mazur H., Pasternak J., Bloki o nadkrytycznych parametrach pracy: nowe materiały hutnicze, technologie wykonania, procesy degradacji oraz ocena trwałości elementów ciśnieniowych kotła. Usługi Komputerowe i Poligraficzne, Gębka Jan, Gębka Dariusz, Bełchatów 2015, 307-316

[3] Chehaibou A.: Metallurgical weldability of stainless steels. Welding International, 20, 7 (2006), 553-556

[4] Nikulina A.A., Bataev A.A., Smirnov A.I., Popelyukh A.I., Burov V.G., Veselov S.V.: Microstructure and fracture behaviour of flash butt welds between dissimilar steels. Science and Technology of Welding and Joining, 20, 2 (2015), 138-144

[5] Łomozik M., Zeman M., Brózda J.: Modern martensitic steels for power industry. Archives of Civil and Mechanical Engineering, 12 (2012), 49-59

[6] Yin Y., Faulkner R., Starr F.: Austenitic steels and alloys for power plants. Structural Alloys for Power Plants Procedia, 45 (2014), 105-152

[7] Kwok C.T., Lo K.H., Chan W.K., Cheng F.T., Man H.C.: Effect of laser surface melting on intergranular corrosion behaviour of aged austenitic and duplex stainless steels. Corrosion Science, 53, 4 (2011), 1581-1591

[8] Nasery Isfahany A., Saghafian H., Borhani G.: The effect of heat treatment on mechanical properties and corrosion behavior of AISI420 martensitic stainless steel. Journal of Alloys and Compounds, 509, 9 (2011), 3931-3936 
[9] Victor B.: Custom beam Shaping for High-Power Fiber Laser Welding. Welding Journal, 90, 6 (2011), 8-17

[10] Lalik S., Adamski J., Balcerzyk A.: Testing of Welded Joints of Gas-Tight Pipe Walls Made of New Generation Martensitic Steel Type VM12-SHC. In: Szczotok A., Szkliniarz A., Mendala J. (eds.), Technologies and Properties of Modern Utility Materials XXIII, 2016, 71-74

[11] Speicher M., Maile K., Klenk A.: Weld Behavior of Martensitic Steels and Ni-based Alloys for High Temperature Components. Procedia Engineering, 55 (2013), 414-420

[12] Abanga R., Liska A., Krautza H.J.: Fireside corrosion of superheater materials under oxy-coal firing conditions. Energy Procedia, 40 (2013), 304-311

[13] Scendo M., Chat M., Antoszewski B.: Oxidation Behaviour of Laser Welding of TP347HFG and VM12-SHC Stainless Steels. International Journal of Electrochemistry Science, 10 (2015), 6359-6377

[14] Blicharski M.: Stale austenityczne odporne na pełzanie [Creep resistant austenitic stainless steels]. In: Hernas A., Pasternak J. (eds.), Powerwelding 2013: III Międzynarodowa naukowo-techniczna konferencja spawalnicza: materiały i technologie stosowane w budowie kotłów o parametrach nadkrytycznych o temperaturze pary do $700^{\circ} \mathrm{C}$. Ostaniec, 3-4 października 2013. RAFAKO, Polskie Towarzystwo Spawalnicze, Gliwice 2013

[15] Tasak E.: Metalurgia spawania. Wydawnictwo JAK, Kraków 2008

[16] Scheaffler A.L.: Constitution diagram for stainless steel weld metal. Metal Progress, 56, 11 (1949), 680-680B

[17] Kotecki D.J., Siewert T.A.:WRC-1992 constitution diagram for stainless steel weld metals: A modification of the WRC-1988 diagram. Welding Journal, 71 (5) 1992, 171-178 